\title{
Analysis and innovative research of Automobile
}

\section{marketing model}

\author{
Tao-ping YAN \\ Faculty of Transportation Engineering \\ HuaiYin Institute of Technology \\ Huai'an, China \\ e-mail: ytp709803816@sohu.com
}

Keywords: car market ; marketing model; analysis of current situation;innovation

Abstract: As the car market structure change and increased competition.Our car marketing model presents a pluralistic development trend, reflecting the spirits of the times. However, there are some problems existing and the traditional marketing model needs changing as soon as possible. In this paper, the existing marketing models at home and abroad are analyzed respectively, its advantages and weaknesses are specified briefly, and then an innovative basic idea of car marketing model is put forward. This paper is to build up a sales model centering on customers and put forward a new marketing model .

\section{Introduction}

According to the China association of automobile manufacturers, In 2012 China auto production and sales of 19.272 million and 19.306 million, up 4.6\% and 4.3\%. Production and sales of 22.117 million cars in 2013 and 21.984 million, year-on-year growth of $14.8 \%$ and $13.9 \%$, respectively, in production and sales hit a record high, set the world record again, first in the world for five consecutive years. The first quarter of 2014, China's automobile production and sales of 5.892 million and 5.922 million, respectively, year-on-year growth of $9.2 \%$. But with the change of market structure and competition, China's auto industry began to shift from a seller's market to a buyer's market, car production and sales showed a trend of slow speed, the imbalance between supply and demand contradictory intensifies. In this situation, we should further develop automobile marketing idea of the profound connotation, development innovation, rich marketing mode, to put China's auto market is more perfect after service, this is the car manufacturers and dealers facing imminent problem.

\section{The development of the automobile marketing mode}

\section{The definition of automobile marketing mode}

Marketing model is the consultive standard style and method of Marketing activities, it's a set of procedural standard forms of marketing based on the characteristics of marketing activities and the stages for consumers to purchase activity of psychological evolution.Therefore, Marketing model can be defined as the union of organic samples by the marketing organization, marketing and marketing concept formed, on this basis, the enterprises can use their resources to develop their own unique form of a set of marketing ${ }^{[1]}$. 


\section{The main types of automobile distribution pattern in our country}

Franchise $4 \mathrm{~S}$ shop

At present this is the main automobile marketing mode in our country, $4 \mathrm{~S}$ shops pattern have a complete car marketing service ability of channel terminal .It includes traditional car sales, providing consumers with good quality car original accessories and car manufacturing enterprise certification of after-sales service, at the same time through information feedback, providing the car manufacturers with effective accurate customer information in time is automobile manufacturing enterprises and reliable sources of information, at the same time guaranteeing the automobile manufacturing enterprise with revenue and profit in the aspect of after-sales.

Automobile trading market

Automobile trading market is mainly refers to small dealers rental market stalls or retail store model, also known as the car market. Car market can reduce the operating cost of operators, and auto market has considerable sales and customer base that makes the car manufacturer can't refuse auto trading market,it has a considerable advantage , Of course, there are obvious shortcomings, many dealers gathered the sham as the genuine, good and bad are intermingled, can not guarantee good service.

Automotive chains

Usually,Automobile sales companies and brands car business agent for the sale of the cooperation agreement in a certain period, this model is not our main sales channels, only plays an important role in automobile brand sales and in the individual regional .

The network marketing

With the rapid development of network information technology, electronic commerce stimulates the development of the automobile industry, automobile network marketing model began to emerge. This model can make the consumer have a better understanding of the latest information of automobile products both conveniently and comprehensively and also can be custom service to meet the personalized needs of consumers, this model is the new tendency of the development of the automobile marketing mode in the information age ${ }^{[2]}$.

\section{Status analysis of domestic automobile marketing mode}

The lag of marketing concept development The development of automobile marketing concept relative lag, lacking of accurate positioning of products,strategic management and development did not establish on market demand in the future .The marketing concept do not really implemented without starting from the interests of the consumers and taking the consumers as the center. Without the extension of automobile marketing concept,it's impossible to make it your own brand, as a result ,the company's market share would be reduced.

The whole quality of the marketing team needs to improve

The key of marketing team is to implement the marketing concept, providing customers with quality service, it is a bridge connected consumers and sales business. Enterprises in auto sales developed countries has a strict degree on automobile marketing personnel and quality requirements, training sales personnel freely, improving their vocational skills is also an important part of the development of the enterprise. In our country, because of most marketing personnel lacking of system training,there are many problems in accessing customer trust and customer demand ${ }^{[3]}$.

Old single marketing means, after-sales service level is not high

In our country, exhibition hall monopoly is still the main method of automobile monopoly sales model ,this sales model method is out-of date and lack of sales management tools, it is in the low level of after-sales service, leading to the low satisfaction of customer,so it can't achieve the result 
that stimulate the automobile consumption. Compared with other countries, marketing is relatively single, lack of diversification of sales, service level also ${ }^{[4]}$.

\section{The innovation of automobile marketing mode}

\section{Set up "Consumer-centric" marketing concept}

Due to the rapid development of market economy and the deepening reform of economic system, in the domestic automobile market competition is increasingly fierce. In view of the current situation, it is imperative for auto makers to change marketing idea . From the point of long-term development, our country automobile marketing should continuously innovate, and establish a "Consumer-centric" marketing idea,only in this way can it adapt to the needs of the development of modern automobile industry. When consumers buy a car, car sales business faces consumers, corporate profits from car turn to the people, this is the requirement of The Times, and also a new growth point. All the information on the contact point for the consumer should be analysis, digging, forecasts the next step requirement, in order to keep and increase consumer loyalty to the brand. This determines that it must take the interests of consumers as the center and bring more value to consumers the domestic automobile production enterprises no matter adopt what a kind of marketing mode. Only in this way can they win customers, the market and the development. Consumer-centric is the first premise, the establishment of the innovation of marketing mode also should start from the whole situation, give full consideration to the social resources and related policy, considering interests of car manufacturers, distributors and consumers, achieve mutual benefit and win-win results and maintain the healthy development of the automobile marketing mode ${ }^{[5]}$.

\section{Develop the APP + 020 automobile marketing mode}

In recent years, the Internet thinking becomes a hot word, and it's quantity of heat of mobile Internet also enhances unceasingly. Although the Internet thought in the traditional industry is a loud, but a whimper. Auto makers had just put the product from the 4S shop to online, then name himself network marketing. Most car companies try to put the Internet as a stunt to attract the attention of consumers, However, the real meaning of the network marketing thinking is far from so simple. Providing users with better travel experience and using the Internet thinking into experiential marketing that is the innovative use of the Internet marketing thinking.

In proportion to the use of mobile Internet users is more than $50 \%$ in various environment , and eighty percent of mobile phone users use theirs'leisure time to the Internet at home, sixty percent of Internet mobile phone users are in the use of cell phones while in transport, when users spend a lot of time and energy on mobile Internet,the value of channel marketing will increasingly highlight, the advantage of APP marketing is more obvious ${ }^{[6]}$.

\section{Conclusion}

Consumer-centric service philosophy will become the mainstream.Marketing should provide consumers with interests, with consumers' needs as the guide. With the mutual penetration of online platform business and offline services business, and mutual cross-border Internet companies and traditional industries, there won't be completely isolated from the Internet in the future of traditional enterprises. Internet and traditional business is harmony in the relationship,the Internet can help traditional enterprise grow fastly, traditional enterprise will also become a member of the Internet world. The evolution of information technology evolution to improve people's living and working forms will also indirectly affect marketing form of innovation and upgrading. Bringing intelligent 
terminal users with unprecedented convenience experience, the APP have also become the brand of "marketing" tool and knocked on the door of brands to mobile marketing,relying on natural precision, position, long tail, interactivity and high user viscosity. APP $+\mathrm{O} 2 \mathrm{O}$ is combination of online platform and offline service, with accurate statistical data of consumer behavior offline as a standard, providing consumers with better products and services.

\section{Reference}

[1] He Jing. car market marketing model. Business review, 2011 (5) : 132

[2] Helen. Thinking about our country automobile industry marketing mode. Business review, 2012 (13) : 115

[3] Gong Jie etc. The status quo of China's automobile marketing mode and innovation direction. Shanghai auto, 2006 (7) : $22-24$

[4] Gu Meiming. Analysis and countermeasures of China's automobile marketing mode. The global market information review, 2011 (35) : 17

[5] Wang Shihong. Modern car marketing model development countermeasures. Management, 2012 (17) : 487

[6] Li Yongna etc. E-commerce application in automobile marketing prospects. Modern economic information, $2010(3): 36-38$ 